\title{
A scientific survey on 1550 cases of oral lesions diagnosed in a Brazilian referral center
}

\author{
ARTUR C. VASCONCELOS ${ }^{1}$, CARLOS ABURAD ${ }^{1}$, IGOR F.P. LIMA ${ }^{2}$, SHEILA M.M. SANTOS ${ }^{3}$, SILAS \\ ANTONIO J. DE FREITAS FILHO ${ }^{4}$, ADEMIR FRANCO ${ }^{5}$, SIGMAR M. RODE ${ }^{6}$ and LUIZ R. PARANHOS ${ }^{2}$
}

${ }^{1}$ Cancer Hospital of Mato Grosso, Av. Historiador Rubens de Mendonça, 5500, Sub. Esquina, 78055-500 Cuiabá, MT, Brazil

${ }^{2}$ Department of Dentistry, Federal University of Sergipe, Av. Governador Marcelo Déda Chagas, 13, São José, 49400-000 Lagarto, SE, Brazil

${ }^{3}$ Post-Graduation Program in Dentistry, Federal University of Sergipe, Rua Cláudio Batista, s/n, Bairro Sanatório, 49060-100 Aracaju, SE, Brazil

${ }^{4}$ Post-Graduation Program in Applied Dental Sciences, School of Dentistry of Bauru, University of São Paulo, Alameda Dr. Octávio Pinheiro Brisolla, 9-75, Vila Universitária, 17012-901 Bauru, SP, Brazil

${ }^{5}$ Department of Stomatology, Federal University of Paraná, Av. Prefeito Lothário Meissner, 632, Jardim Botânico, 80210-170 Curitiba, PR, Brazil

${ }^{6}$ Paulista State University Júlio de Mesquista Filho, Science and Technology Institute, Campus

São José dos Campos, Department of Dental Materials and Prostheses, Av. Engenheiro Francisco José Longo, 777, Jardim São Dimas, 12201-970 São José dos Campos, SP, Brazil

Manuscript received on January 4, 2017; accepted for publication on March 14, 2017

\begin{abstract}
The present study aimed to perform an epidemiological survey on the prevalence rate of oral lesions diagnosed in a referral center in Brazil and to establish association between the lesions and the age and gender of the affected patients. This analytical observational study analyzed 3521 medical records of anatomopathological exams of the Pathological Anatomy and Cytopathology Laboratory of the Cancer Hospital of the state of Mato Grosso (Brazil), from December 2011 to September 2015. A total of 1550 relevant medical records was detected. Patients aging between 41 and 60 consisted of $42.84 \%$ of the sample. Males were more affected than females $(60.13 \%)$. Inflammatory processess consisted of the most prevalent diagnosis $(43.29 \%)$, followed by squamous cell carcinoma $(6.06 \%)$, and periapical granuloma $(5.23 \%)$. Oral health public policies must give major attention to Brazilian males aged between the fourth and sixth decades of life in order to improve their quality of life.
\end{abstract}

Key words: diagnosis, oral medicine, pathology, stomatology.

\section{INTRODUCTION}

In dental routine, the early recognition of oral lesions is important for clinical diagnosis (Cunha et al. 2013), which often presents conditions

Correspondence to: Luiz Renato Paranhos

E-mail: paranhos.lrp@gmail.com from inflammatory processes, recurrent aphthous stomatitis, granulomas, and fibromas (Gonçalves et al. 2007). Several studies (Lima et al. 2008, Mathew et al. 2008, Kniest et al. 2011, Ghanaei et al. 2013) have been developed in order to define the most frequent oral lesions, but it is known that culture, gender, age, ethnicity, and habit factors 
may have a significant influence on the prevalence of lesions (Cebeci et al. 2009, Henrique et al. 2009). Moreover, the socioeconomic differences of population groups may also have such influence, considering it is mostly associated with malnutrition, poor oral hygiene, and difficult access to healthcare (Crivelli et al. 1988). Thus, it is up to dentists to learn, through epidemiological studies, about the most frequent oral lesions and diseases among their own population, in order to interpret correctly the changes of tissues and oral structures and perform an accurate diagnosis (Gemaque et al. 2014).

With increasing age, the frequency of oral lesions and diseases also increases, and men are most often affected than women (Cruz et al. 2005, Leite Segundo et al. 2003, Nascimento et al. 2005, AlMobeeriek and Aldosari 2009). The development of such conditions may affect the quality of life of individuals, besides compromising their daily activities (Tarquinio et al. 2013). Learning about oral diseases and lesions through epidemiological studies plays an important role in public health, making such studies valuable tools to describe the health conditions of the population, investigate their determinants, and for health actions aiming to change such conditions (Oliveira et al. 1998, Nascimento et al. 2005, Pereira et al. 2013).

Thus, considering the importance of knowing the most frequent oral lesions in the state of Mato Grosso, Brazil, for creating public health policies, this study aimed to perform an epidemiological survey in a specific population by consulting the records of the Pathological Anatomy and Cytopathology Laboratory of the Cancer Hospital of Mato Grosso, searching for oral lesions diagnosed from December 2011 to September 2015, and establishing a relation of its classification regarding occurrence, age, and gender.

\section{MATERIALS AND METHODS}

\section{ETHICAL RESEARCH CRITERIA}

TheEthics Committee on Human Research approved this study (Certificate of Ethical Consideration Presentation: 48685715.9.0000.5165), which complied with the Declaration of Helsinki. Considering it is an observational and analytical research on secondary data, the Informed Consent Form was not applicable.

\section{TYPE OF STUDY AND SAMPLE DESCRIPTION}

The work consisted of a quantitative analytical observational study that analyzed 3,521 medical records of anatomopathological examinations, diagnosed and stored by the Pathological Anatomy and Cytopathology Laboratory of the Cancer Hospital of Mato Grosso, Cuiabá, Brazil, from December 2011 to September 2015. As inclusion criteria, only medical records of oral lesions with digital records were surveyed. All histopathological medical records were excluded, resulting in a final sample of 1.550 records.

\section{METHOD}

The histopathological diagnoses generated a list of 99 different types of lesions detected in the present study. When the diagnosis required an immunohistochemical study, it was classified as "other".

The diseases identified were classified in 13 groups, presented in Table I, based on the histogenesis according to the model by Vale et al. (2013).

Age group was divided and organized in intervals of every 20 years of age, as follows: from 0 to 20 , from 21 to 40 , from 41 to 60 , from 61 to 80 , and over 80 .

Data were collected from the digital file, organized, and tabulated in a Microsoft Excel ${ }^{\mathrm{TM}}$ (Redmond, WA, USA) spreadsheet, aiming 
to perform the quantitative treatment of the variables analyzed, which were taken from the medical records studied. The analysis generated the following independent variables: time period researched, age, gender, classification of diseases and histopathological diagnosis. The obtained data was reported in the present study descriptively.

\section{RESULTS}

Data were collected complying with a distribution of forms between the years of 2011 and 2015. In 2011, a lower amount of forms was analyzed, resulting in 39 (2.52\%), because the access to such documents was only possible in a single month of service. However, between 2012 and 2015, the amount of services was regular. In 2012, 377 medical records were analyzed, corresponding to $24.32 \%$, while in 2013,368 medical records (23.74\%) were analyzed. In 2014 and 2015, 390 and 376 anatomopathological records were issued, respectively, corresponding to $49.42 \%$ of the sample.

The sample was formed mostly by individuals aged from 41 to 60 , corresponding to $42.84 \%$ of

TABLE I

Grouping of diseases identified in the records of anatomopathological examinations.

\begin{tabular}{cc}
\hline $\begin{array}{c}\text { Group } \\
\text { Number }\end{array}$ & Classification of Diseases \\
\hline 1 & Inflammatory lesion \\
2 & Osseous and fibro-osseous lesions \\
3 & Mesenchymal tissue lesions \\
4 & Vascular lesions \\
5 & Pigmented lesions \\
6 & Non-glandular epithelial tissue lesions \\
7 & Salivary gland lesions \\
8 & Odontogenic tumors \\
9 & Non-inflammatory odontogenic cysts \\
10 & Non-odontogenic cysts \\
11 & Fungal lesions \\
12 & Regular tissue \\
13 & Other \\
\hline
\end{tabular}

the total, followed by the age group from 21 to 40 , which corresponded to $21.87 \%$ of the sample. The groups from 0-20 years and 61-80 years of age corresponded, respectively, to $12.38 \%$ and $21.54 \%$. The patients over 80 years of age corresponded to only $1.55 \%$ of cases. The male gender was more frequent, with rate of $60.13 \%$ of the cases analyzed, while the female gender corresponded to $39.87 \%$.

Regarding diagnosis by category, the most frequent one was named inflammatory process, appearing in 671 medical records and corresponding to $43.29 \%$, followed by squamous cell carcinoma and periapical granuloma, with $6.06 \%$ and $5.23 \%$, respectively. The diagnoses classified as inflammatory lesion (inflammatory process and periapical granuloma) added to other diagnoses figured $64.65 \%$ of all cases analyzed, followed by the ones classified as non-glandular epithelial tissue lesion (squamous cell carcinoma) with $9.94 \%$ of all cases (Table II).

Table III presents the diagnoses of lesions divided by the age groups identified in the medical records. Thus, it is noticed that the lesions evolved along with the increase in age groups. For instance,

TABLE II

Absolute and relative frequency of lesion diagnoses.

\begin{tabular}{ccc}
\hline Category of the Lesion & $\mathbf{N}$ & $\mathbf{\%}$ \\
\hline Inflammatory lesion & 1002 & 64.65 \\
Osseous and fibro-osseous lesions & 45 & 2.90 \\
Mesenchymal tissue lesions & 71 & 4.58 \\
Vascular lesions & 7 & 0.45 \\
Pigmented lesions & 4 & 0.26 \\
Non-glandular epithelial lesions & 154 & 9.94 \\
Salivary gland lesions & 62 & 4.00 \\
Odontogenic tumors & 36 & 2.32 \\
Non-inflammatory odontogenic cysts & 11 & 0.71 \\
Non-odontogenic cysts & 14 & 0.90 \\
Fungal lesions & 17 & 1.10 \\
Regular tissue & 110 & 7.10 \\
Other & 17 & 1.10 \\
\hline
\end{tabular}


TABLE III

Lesion diagnoses and ages.

\begin{tabular}{|c|c|c|c|c|c|c|c|c|c|c|}
\hline \multirow[b]{2}{*}{ Diagnosis } & \multicolumn{5}{|c|}{$\mathbf{N}$} & \multicolumn{5}{|c|}{$\%$} \\
\hline & $\begin{array}{c}0-20 \\
\text { years }\end{array}$ & $\begin{array}{l}21-40 \\
\text { years }\end{array}$ & $\begin{array}{l}41-60 \\
\text { years }\end{array}$ & $\begin{array}{l}61-80 \\
\text { years }\end{array}$ & $\begin{array}{c}>80 \\
\text { years }\end{array}$ & $\begin{array}{c}0-20 \\
\text { years }\end{array}$ & $\begin{array}{l}21-40 \\
\text { years }\end{array}$ & $\begin{array}{l}41-60 \\
\text { years }\end{array}$ & $\begin{array}{l}61-80 \\
\text { years }\end{array}$ & $\begin{array}{c}>80 \\
\text { years }\end{array}$ \\
\hline $\begin{array}{l}\text { Inflammatory } \\
\text { process }\end{array}$ & 48 & 126 & 323 & 164 & 10 & 25.4 & 37.2 & 48.6 & 49.1 & 41.7 \\
\hline $\begin{array}{l}\text { Squamous cell } \\
\text { carcinoma }\end{array}$ & 1 & 5 & 47 & 36 & 5 & 0.5 & 1.5 & 7.1 & 10.8 & 20.8 \\
\hline $\begin{array}{l}\text { Periapical } \\
\text { granuloma }\end{array}$ & 10 & 29 & 29 & 10 & 3 & 5.3 & 8.6 & 4.4 & 3.0 & 12.5 \\
\hline Radicular cyst & 9 & 22 & 29 & 6 & 0 & 4.8 & 6.5 & 4.4 & 1.8 & 0.0 \\
\hline $\begin{array}{c}\text { Pericoronal } \\
\text { pouch }\end{array}$ & 24 & 21 & 6 & 0 & 0 & 12.7 & 6.2 & 0.9 & 0.0 & 0.0 \\
\hline Total $(\mathrm{N})$ & 189 & 339 & 664 & 334 & 24 & - & - & - & - & - \\
\hline
\end{tabular}

if we consider the most frequent diagnosis (inflammatory process), we notice that the group from 0 to 20 years old had 48 occurrences, while in the next age group, from 21 to 40, 126 occurrences were recorded, and there were 323 cases for the age group from 41 to 60 .

Table IV presents the frequency of the main lesions diagnosed. The lesions included in the inflammatory process were the most frequent, corresponding to $43.29 \%$ of the sample, followed by the squamous cell carcinoma and periapical granuloma, with $6.06 \%$ and $5.23 \%$, respectively.

\section{DISCUSSION}

This study sought to perform an epidemiological survey through the retrospective analysis of oral lesions diagnosed at the Pathological Anatomy and Cytopathology Laboratory of the Cancer Hospital of Mato Grosso, Cuiabá, Brazil, from December 2011 to September 2015, and to report their prevalence and distribution with age and gender. Hence, it was possible to verify that lesions from inflammatory processes, squamous cell carcinoma, and periapical granuloma were more frequent in the sample analyzed.

The early recognition of oral lesions, their etiology and epidemiological aspects are important for the clinical diagnosis, considering it could potentially reduce the chances of evolution through prevention actions, providing an improved diagnosis (Cunha et al. 2013). Several epidemiological studies (Lima et al. 2008, Mathew et al. 2008, Kniest et al. 2011, Ghanaei et al. 2013) have been developed in order to define the most frequent oral lesions, but it is known that culture, gender, age, ethnicity, and habit factors may have a significant influence on the prevalence of lesions in a given population (Cebeci et al. 2009, Henrique et al. 2009). Thus, knowing such lesions, as well as their severity and stage, becomes an essential task in dental routine (Ali et al. 2013).

The search for dental and health care has considerably increased over the last years, as well as the incidence of oral and maxillofacial lesions (Kleinman et al. 1994, Nascimento et al. 2005). Although authors (Wang et al. 2013) affirm that women seek these services more often, in our study $60.13 \%$ of the sample was composed by male individuals, while $39.87 \%$ was composed by women. In a study (Mehrotra et al. 2010) with 3,030 patients, $71 \%$ were men and only $29 \%$ were women. Similarly, in an analysis of 720 individuals, there was a higher prevalence of men, corresponding to $52.8 \%$ of cases (Tarquinio et al. 2013). 
TABLE IV

Absolute and relative frequency of diagnosed lesions.

\begin{tabular}{cccc}
\hline Variable & Category & N & \% \\
\hline Diagnosis & Inflammatory process & 671 & 43.29 \\
& Squamous cell carcinoma & 94 & 6.06 \\
& Dental granuloma & 81 & 5.23 \\
Radicular cyst & 66 & 4.26 \\
Hyperkeratosis and & 43 & 2.77 \\
Acanthosis & & \\
Inflammatory fibrous & 42 & 2.71 \\
hyperplasia & 39 & 2.52 \\
Actinic cheilitis & 34 & 2.19 \\
& Pyogenic granuloma & 32 & 2.06 \\
& Fibroma & 27 & 1.74 \\
& Traumatic fibroma & 25 & 1.61 \\
\hline
\end{tabular}

Inflammation consists of a physiopathological phenomenon (Hasturk et al. 2012) and the oral cavity is an anatomical site with potential for developing inflammatory processes from the loss of balance between the oral microbiota and the immunological response, resulting in morphological changes (Avila et al. 2009). In our study, the inflammatory process was the most frequent lesion, corresponding to $43.29 \%(n=671)$ of lesions. Moreover, this lesion was more frequent in men $(67.8 \%)$, which indicates a need for more attention to this group concerning oral health. The low search for healthcare by men occurs mostly by the social feature of masculinity such as superiority, self-sufficiency, and dominance, which constitutes a barrier for seeking care (Courtenay 2000, Mahalik et al. 2003). Studies (Mehrotra et al. 2010, Ali et al. 2013) with similar objectives also presented high frequencies of lesions from inflammatory processes.

Squamous cell carcinoma is a malignant mouth neoplasia that may be presented clinically as leukoplakic or erythroleukoplakic lesions with endophytic or exophytic growth (Ivan et al. 2006). When assessing the most frequent oral lesions in
2,161 Indians, among the malignant conditions, all patients were diagnosed with squamous cell carcinoma (Thada and Pai et al. 2014). Moreover, in a sample of 59,273 cases, the frequency of this disease was 53\% among epithelial lesions (Shahsavari et al. 2016). The information obtained in this study corroborate findings in the literature, considering this lesion was the second most frequent in our analysis, corresponding to $6.06 \%$ of lesions ( $\mathrm{n}=94)$ with more prevalence in men (76.6\%). The lack of care and consideration with human health reveals greater impairment of men (Wang et al. 2013), making the early diagnosis of potentially malignant lesions difficult, as well as the involvement of men with risk factors (Bertakis et al. 2000). On the other hand, in an analysis of 530 patients, there was no case of squamous cell carcinoma, which also revealed high variety regarding types and frequency of oral lesions (Ali et al. 2013).

Periapical granuloma was the third most frequent lesion in our study. This lesion is characterized by chronic inflammation in the periapical region, constituted by a granulation tissue and abundant inflammatory infiltrate (Omoregie et al. 2011). The male gender had more occurrences (67.9\%), especially from 20 to 40 years old. Simões et al. (2007), when assessing the prevalence of oral diseases in a sample of 1,040 anatomopathological records, found that periapical granuloma was the most frequent disease, corresponding to $63 \%$ of the lesions assessed, corroborating our findings. Similarly, Diegues et al. (2011) analyzed 1,788 medical records and $42 \%$ of cases was diagnosed with periapical granuloma, which reinforces the importance of a correct histopathological study of inflammatory periapical lesions and the establishment of an effective treatment.

Pyogenic granuloma, mucocele, and traumatic fibroma were also found in the present study, but with lower frequency when compared to lesions from inflammatory processes, squamous cell 
carcinoma, and periapical granuloma. Several studies (Mathew et al. 2008, Ali et al. 2013, Shahsavari et al. 2016) corroborate our results. Shahsavari et al. (2016) found pyogenic granuloma in only $3.2 \%$ of epithelial lesions, which was similar to our result (2.19\%). Moreover, in another study (Ali et al. 2013), mucocele lesions were found in only $0.7 \%$ of cases and $4.9 \%$ corresponded to traumatic fibroma, while our casuistry showed and even lower value $(1.74 \%)$. The literature on the prevalence of radicular cyst, hyperkeratosis and acanthosis, inflammatory fibrous hyperplasia, and actinic cheilitis is scarce, although it was found in this study but with low frequency.

Thus, this study highlights the prevalence of lesions from inflammatory processes, squamous cell carcinoma, and periapical granuloma in individuals from the region of the state of Mato Grosso, Brazil, in a sample of 1550 histopathological records. We believe that the results hereby presented will be fundamentally important for establishing new conducts, with greater emphasis in early diagnosis and the severity of such lesions, aiming to aid the establishment of primary prevention actions. Hence, further studies should be performed in order to confirm and reinforce such findings.

\section{CONCLUSIONS}

The highest prevalence rate of lesions in the oral mucosa was from the inflammatory process, followed by squamous cell carcinoma and dental granuloma, whereas more lesions were detected in males in the fourth decade of life. Hence, it is vital to admit the need for a program of patient guidance and prevention, especially for the male gender, considering that this group uses to search less for dental care compared to females.

\section{REFERENCES}

ALI M, JOSEPH B AND SUNDARAM D. 2013. Prevalence of oral mucosal lesions in patients of the Kuwait University Dental Center. Saudi Dent J 25: 111-118.

AL-MOBEERIEK A AND ALDOSARI AM. 2009. Prevalence of oral lesions among Saudi dental patients. Ann Saudi Med 29: 365-368.

AVILA M, OJCIUS DM AND YILMAZ O. 2009. The Oral Microbiota: Living with a Permanent Guest. DNA Cell Biol 28: 405-411.

BERTAKIS KD, AZARI R, HELMS LJ, CALLAHAN EJ AND ROBBINS JA. 2000. Gender differences in the utilization of health care services. J Fam Pract 49: 147152.

CEBECI ARI, GÜLSAHI A, KAMBUROGLU K, ORHAN BK AND ÖZTAS B. 2009. Prevalence and distribution of oral mucosal lesions in an adult Turkish population. Med Oral Patol Oral Cir Bucal 14: 272-277.

COURTENAY W. 2000. Engendering health: a social constructionist examination of men's health beliefs and behaviours. Psychol Men Masculinity 1: 4-15.

CRIVELLI MR, AGUAS S, ADLER I, QUARRACINO C AND BAZERQUE P. 1988. Influence of socioeconomic status on oral mucosa lesion prevalence in schoolchildren. Community Dent Oral Epidemiol 16: 58-60.

CRUZ MCFN, ALMEIDA KGB, LOPES FF, BASTOS EG AND FREITAS RA. 2005. Levantamento das biópsias da cavidade oral realizadas no hospital universitário Unidade Presidente Dutra / UFMA, da cidade de São Luís -MA, no período de 1992 a 2002. Rev Bras Patol Oral 4: 185-188.

CUNHAFFA, SILVA MBF, PANZARELLAFK, JUNQUEIRA JLC AND OLIVEIRA LB. 2013. Oral lesions diagnosed in a public oral pathology laboratory. Rev Gaúcha Odontol 61: 595-601.

DIEGUES LL, COLOMBO ROBAZZA CR, COSTA HANEMANN JA, COSTA PEREIRA AA AND SILVA CO. 2011. Correlation between clinical and histopathological diagnoses in periapical inflammatory lesions. J InvestigClin Dent 2: 184-186.

GEMAQUE K, NASCIMENTO GG, JUNQUEIRA JLC, ARAUJO VC AND FURUSE C. 2014. Prevalence of Oral Lesions in Hospitalized Patients with Infectious Diseases in Northern Brazil. Sci World J 2014: 1-5.

GHANAEI FM, JOUKAR F, RABIEI M, DADASHZADEH A AND VALESHABAD AK. 2013. Prevalence of Oral Mucosal Lesions in an Adult Iranian Population. Iran Red Crescent Med J 15: 600-604.

GONÇALVES WC, CHI AC AND NEVILLE BW. 2007. Common Oral lesions: Part I. Superficial mucosal lesions. Am Fam Physician 75: 501-507. 
HASTURK H, KANTARCI A AND VAN DYKE TE. 2012. Oral Inflammatory Diseases and Systemic Inflammation: Role of the Macrophage. Front Immunol 3: 1-17.

HENRIQUE PR, JÚNIOR BAZAGA M, ARAÚJO VC, JUNQUEIRA JLC AND FURUSE C. 2009. Prevalência de alterações da mucosa bucal em indivíduos adultos da população de Uberaba, Minas Gerais. Rev Gaúcha Odontol 57: 261-267.

IVAN DF, RODRIGO G, JANETE GL AND LÜCKMANN FSM. 2006. Carcinoma de células escamosas em rebordo alveolar inferior: diagnóstico e tratamento odontológico de suporte. J Bras Patol Med Lab 42: 279-283.

KLEINMAN DV, SWANGO PA AND PINDBORG JJ. 1994. Epidemiology of oral mucosal lesions in United States schoolchildren: 1986-87. Community Dent Oral Epidemiol 22: $243-253$.

KNIEST G, STRAMANDINOLI RT, ÁVILA LFC AND IZIDORO ACAS. 2011. Frequency of oral lesions diagnosed at the Dental Specialties Center of Tubarão (SC). RSBO 8: 13-17.

LEITE SEGUNDO AVL, SILVA UH AND MARTELLI PJL. 2003. Estudo retrospectivo de exames anatomopatológicos do Laboratório de Anatomia Patológica da Faculdade de Odontologia de Caruaru / PE. Odontologia Clin Cientif 2: $15-20$

LIMA GS, FONTES ST, ARAÚJO LMA, ETGES A, TARQUÍNIO SBC AND GOMES APN. 2008. A survey of oral and maxillofacial biopsies in children. A single-center retrospective study of 20 years in Pelotas-Brazil. J Appl Oral Sci 16: 397-402.

MAHALIK JR, GOOD G AND ENGLAR-CARLSON M. 2003. Masculinity scripts, presenting concerns, and help seeking: implications for practice and training. Prof Psychol Res Pr 34: 123-131.

MATHEW AL, PAI KM, SHOLAPURKAR AA AND VENGAL M. 2008. The prevalence of oral mucosal lesions in patients visiting a dental school in Southern India. Indian J Dent Res 19: 99-103.

MEHROTRA R ET AL. 2010. Prevalence of oral soft tissue lesions in Vidisha. BMC Res Notes 3: 1-6.

NASCIMENTO GJF, PARAÍSO DP, GÓES PSA AND SOBRAL APV. 2005. Estudo epidemiológico de 2.147 casos de lesões bucomaxilofaciais. Rev Bras Patol Oral 4: 82-89.

OLIVEIRA AGRC, UNFER B, COSTA ICC, ARCIERI RM, GUIMARÃES LOC AND SALIBA NA. 1998. Levantamentos epidemiológicos em saúde bucal: análise da metodologia proposta pela Organização Mundial da Saúde. Rev Bras Epidemiol 1: 177-189.

OMOREGIE FO, OJO MA, SAHEEB B AND ODUKOYA O. 2011. Periapical granuloma associated with extracted teeth. Niger J Clin Pract 14: 293-296.

PEREIRA TTM, GAETTI-JARDIM EC, CASTILLO KA, BARROS PAES GD AND BARROS RMGD. 2013. Levantamento Epidemiológico das Doenças de Boca: Casuística de Dez Anos. Arch Health Invest 2: 15-20.

SHAHSAVARI F, SADRI D, JOLEHAR M AND FARZANEHNEJAD R. 2016. Epidemiologic Study of the Prevalence of Oral Mucosal Lesions in the Biopsied Samples at Buali and Imam Khomeini Hospitals from 2000 to 2014. J Res Dentomaxillofac Sci 1: 28-33.

SIMÕES CA, LINS RC, HENRIQUES ACG, CAZAL C AND CASTRO JFL. 2007. Prevalence of diagnostics lesions in Maxillofacial Region in Oral Pathology Laboratory Federal University of Pernambuco. Int J Dent 6: 35-38.

TARQUINIO SBC ET AL. 2013. Factors associated with prevalence of oral lesions and oral self-examination in young adults from a birth cohort in Southern Brazil. Cad Saúde Pública 29: 155-164.

THADA SR AND PAI KM. 2014. Prevalence of habit associated oral mucosal lesions among the outpatients - A prospective cross sectional study. Int J Health Sci 2: $263-$ 273.

VALE EB, PEREZ FMM, RODRIGUES GLC, CARVALHO EJA, CASTRO JR AND PEREZ DEC. 2013. A review of oral biopsies in children and adolescents: a clinicopathological study of a case series. J Clin Exp Dent 5: 144-149.

WANG Y, HUNT K, NAZARETH I, FREEMANTLE N AND PETERSEN I. 2013. Do men consult less than women? An analysis of routinely collected UK general practice data. BMJ Open 3: 1-7. 